\title{
技術論文
}

\section{固相抽出による前濃縮を利用したマイクロペーパー 分析デバイスによる六価クロムの高感度分析}

\author{
浅 野 比 ${ }^{* 1}$, 前田大志朗 ${ }^{2}$, 白石 幸英 $^{2}$
}

\begin{abstract}
高選択性樹脂カートリッジを用いた固相抽出による六価クロム $(\mathrm{Cr}(\mathrm{VI}))$ の濃縮と Microfluidic paperbased analytical device（ $\mu \mathrm{PAD} ） を$ 組み合わせた $\mathrm{Cr}(\mathrm{VI})$ の高感度定量法を開発した. $\mu \mathrm{PAD} に は \mathrm{Cr}(\mathrm{VI})$ の発 色試薬としてジフェニルカルバジドを担持させておき, 呈色した $\mu \mathrm{PAD}$ の画像解析から強度を求め, $\operatorname{Cr}(\mathrm{VI})$ の定量を行った， $\mu \mathrm{PAD} へ の$ 試料溶液の滴下体積について検討した結果, 滴下体積の増加に伴い強度も直線 的に増加し, 感度の向上がみられた. 共存成分の影響について検討を行ったところ, $\mathrm{Ba}(\mathrm{II}), \mathrm{Ca}(\mathrm{II}), \mathrm{Cu}(\mathrm{II})$, $\mathrm{Fe}(\mathrm{III}), \mathrm{Mg}(\mathrm{II}), \mathrm{Ni}(\mathrm{II})$ 及び $\mathrm{Pb}(\mathrm{II})$ が $\mathrm{Cr}(\mathrm{VI})$ の 10 倍の濃度で存在しても, 定量への影響はみられなかった. $\mathrm{Cr}(\mathrm{VI})$ 濃度 $0 \sim 20 \mu \mathrm{g} \mathrm{L}^{-1}$ の範囲で, 決定係数 0.9978 の良好な直線の検量線が得られた. 検出限界及び定量 下限はそれぞれ， $1.3 \mu \mathrm{g} \mathrm{L}^{-1}$ 及び $4.3 \mu \mathrm{g} \mathrm{L}^{-1}$ であった．本法を河川水及び水道水へ応用したところ，共存物質 の影響もみられず, $\mathrm{Cr}(\mathrm{VI})$ は定量的に回収され，本分析法の有用性が示された.
\end{abstract}

\section{1 緒言}

クロム $(\mathrm{Cr})$ は重要な工業原料として, めっき, 顔料, 染色，有機合成，皮革など，幅広く利用されている ${ }^{1)}$. Cr を使用する工場では, Cr を含む廃水，排ガス及び固形廃棄 物が生じ，使用後に廃棄された，それら製品による環境污 染が懸念されている。 Crの主な酸化状態は三価（Cr(III)） と六価 $(\mathrm{Cr}(\mathrm{VI}))$ であるが ${ }^{2)}, \mathrm{Cr}(\mathrm{III})$ は正常な糖, タンパ ク質及び脂質の代謝に関与し, $\mathrm{Cr}(\mathrm{III})$ の欠乏はインスリン 抵抗性, 高血糖や脂質代謝異常を引き起こす ${ }^{3)}$. 一方,

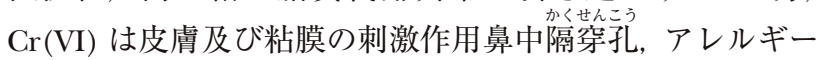
性皮膚炎，ぜん息などの症状をもたらす ${ }^{4)}$ 。また，呼吸器 系, 特に肺がんなどを発症させる発がん性物質としても知 られている。このように $\mathrm{Cr}$ は酸化状態によって性質が異 なるため, 特に毒性の強い $\mathrm{Cr}(\mathrm{VI})$ を選択的に定量すること は極めて重要である.

2020 年 4 月より $\mathrm{Cr}(\mathrm{VI})$ の水道水質基準が，以前の 0.05 $\mathrm{mg} \mathrm{L}^{-1}$ から $0.02 \mathrm{mg} \mathrm{L}^{-1}$ に改正され ${ }^{5)}$, さらに高感度な分析 が求められるようになった. $\mathrm{Cr}(\mathrm{VI})$ の分析には, $\mathrm{Cr}(\mathrm{VI})$ と $\operatorname{Cr}(\mathrm{III})$ の分別を行った後, 誘導結合プラズマ質量分析 法 $^{6}$, 誘導結合プラズマ発光分析法 ${ }^{7)}$ 及び原子吸光分析 法 $^{8) \sim 10)}$ に供する高感度な分析方法が報告されている。ま た，共沈や陽イオン交換樹脂カラム及び紫外線ランプを組

\footnotetext{
*E-mail : asano@rs.socu.ac.jp

${ }^{1}$ 山陽小野田市立山口東京理科大学共通教育センター：756-0884 山口県山陽小野田市大学通 1-1-1

2 山陽小野田市立山口東京理科大学工学部応用化学科 : 756-0884 山口県山陽小野田市大学通 1-1-1
}

み込んだフローインジェクション分析法（FIA $)^{1112) ， ~ カ ゙ ラ ~}$ スビーズを用いるシーケンシャルインジェクション分析法 $(\mathrm{SIA})^{13)}$ もオンラインで分別, 濃縮を行い, $\mathrm{Cr}(\mathrm{VI})$ 分析を 可能にしている. 一方, $\mathrm{Cr}(\mathrm{VI})$ と $\mathrm{Cr}(\mathrm{III})$ を分別すること なく分析することが可能な, 放射光 X 線吸収端近傍構 造 ${ }^{1415)}$ や実験室系 X 線吸収分光装置 ${ }^{16)}$ による分析法も報告 されている. また, $\mathrm{Cr}(\mathrm{VI})$ と選択的に反応するジフェニル

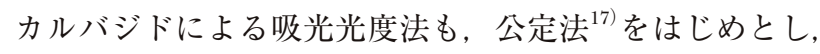
数多く利用されている ${ }^{18) \sim 22)}$.

近年，クロマトろ紙などに流路を施し，分析目的成分と 反応して呈色する試薬をあらかじめ担持しておき，発色の 度合いから定量が可能な Microfluidic paper-based analytical device $(\mu \mathrm{PAD})^{23) \sim 29)}$ に関する研究が数多く報告されて いる. $\mu \mathrm{PAD}$ の特徵として, 安価に作製可能, 修飾が容易, 使用する試薬量の低減が可能, 軽量で携帯性・運搬性に優 れている，などがあげられる．また，セルロースの毛管現 象と親水性により, ポンプを使用せず送液が可能であり， 目視による色見本との比較またはカメラで撮影した画像を PCで解析することで定量可能なため, 検出器を必要とし ない. 先に述べたように，機器分析は高感度な分析を可能 にするが，可搬型の FIA や SIA を除けばオンサイトで分析 することは困難である。一方，可搬型の FIA や SIA などは オンサイト分析が可能であるが, ポンプやバルブ, 検出器 などを駆動させるためにはバッテリーが不可欠であり，装 置はやや大掛かりである。機器分析に対して $\mu \mathrm{PAD}$ は上 述の特徵を有することから, 分析装置や電力のない実験室 外での分析や, インフラが整備されていない開発途上国な 
(a)

(b)

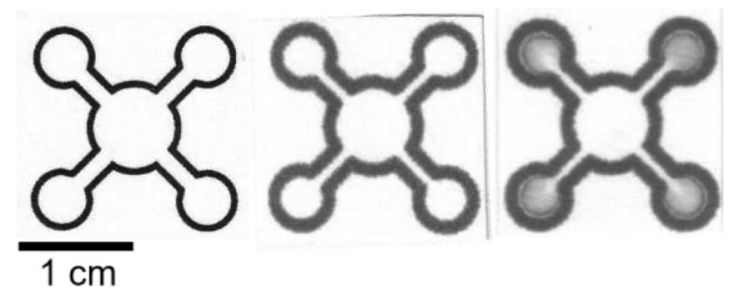

Fig. 1 Design of $\mu \mathrm{PAD}$

(a) after printing, (b) after heating, (c) after analysis.

どで非常に有用である.

$\mu \mathrm{PAD}$ は有用な分析デバイスであるものの，そのまま使 用するにはやや感度不足である，例えば，前濃縮のない $\mu \mathrm{PAD}$ による $\mathrm{Cr}(\mathrm{VI})$ の検出限界は, 数 $10 \mathrm{mg} \mathrm{L}^{-1}$ からサブ $\mathrm{mg} \mathrm{L}^{-1}$ レベル2830)31) であり, 水質基準值 $\left(0.02 \mathrm{mg} \mathrm{L}^{-1}\right)$ レ ベルの分析は困難である．著者らは以前，フォトリソグラ フィーによる修飾方法で作成した $\mu \mathrm{PAD} に よ る \mathrm{Cr}(\mathrm{VI})$ の 定量法について報告した ${ }^{28)}$. この修飾方法は, 流路の安定 した $\mu \mathrm{PAD}$ の作製が可能であったが，紫外線照射よる検出 部の変色ため, ブランク值の上昇をもたらした，結果とし て検出限界が $30 \mathrm{mg} \mathrm{L}^{-1}$ となり, 高感度な分析が困難で あった、したがって, 本研究では, ブランク值低減のため, 呈色部が変色しない修飾法であるワックスプリンターを用 いる修飾法を選択した。一方, 感度不足を補うため, 電気 膜マイクロ抽出法 ${ }^{29}$, 吸着ろ紙デイスク ${ }^{32)}$ ，イオン濃度分 極 ${ }^{33)}$, 溶媒の加熱蒸発 ${ }^{34)}$ な゙の前濃縮と $\mu \mathrm{PAD}$ を組み合わ せた分析手法も報告されている．しかしながら，これまで 固相抽出による前濃縮と $\mu \mathrm{PAD}$ を組み合わせた高感度な分 析法は報告されていない，そこで, 本研究では, 前濃縮と して, $\mathrm{Cr}(\mathrm{VI})$ の吸着に優れた高選択性樹脂 ${ }^{20)}$ を用いた固相 抽出と $\mu \mathrm{PAD}$ を組み合わせた $\mathrm{Cr}(\mathrm{VI})$ の高感度分析方法に ついて検討を行った.

\section{2 実験}

\section{$2 \cdot 1$ 試 薬}

発色試薬として，1,5-ジフェニルカルバジド（DPC，ナ カライテスク製） $1 \mathrm{~g}$ をアセトンに溶解し， $100 \mathrm{~mL}$ に定容 したものを用いた. $\mathrm{Cr}(\mathrm{VI})$ 標準液は, 和光純薬工業製のク ロム標準液（Cr1000）（1000 $\mathrm{mg} \mathrm{L}^{-1} ）$ を, 適宜希釈して用 いた，塩酸及び塩化ナトリウムは，和光純薬工業製特級を 純水で適宜希釈して使用した。緩衝液は和光純薬工業製の リン酸二水素ナトリウム及びリン酸水素二ナトリウムを使 用し, pH 7 に調整したものを用いた。濃縮のための高選択 性樹脂として，ジーエルサイエンス製 MetaSEP AnaLig ${ }^{\oplus}$ Cr-02を用いた。

\section{$2 \cdot 2 \mu \mathrm{PAD}$ の作製}

作製した 4 チャネル型の $\mu \mathrm{PAD}$ を Fig. 1 （a），（b）に示 す。パターンは, Microsoft Wordにより作製し，ワックス プリンター（Xerox, ColorQube 8580）を用いてクロマト ろ紙（Advantec, No.51B，厚さ $0.17 \mathrm{~mm}$ ）に印刷した（Fig. 1 (a))。印刷したろ紙を, 乾燥器 (Advantec, FS-620) で $120{ }^{\circ} \mathrm{C}, 2$ 分間加熱し, 印刷された箇所のワックスインク を融解することで流路の枠 (疎水壁 ${ }^{35}$ 35) を形成し, Fig. 1 （b）に示すような流路を構築した.

\section{$2 \cdot 3$ 固相抽出による $\mathrm{Cr}(\mathrm{VI})$ の濃縮}

$\mathrm{Cr}(\mathrm{VI})$ の濃縮操作は古庄ら ${ }^{20)}$ の報告にお打むね準拠し た. 高選択性樹脂カートリッジに $3 \mathrm{~mol} \mathrm{~L}^{-1}$ 塩酸 $3 \mathrm{~mL}$ を通 液し, 純水 $10 \mathrm{~mL}$ で洗浄後, $5 \mathrm{mmol} \mathrm{L}^{-1}$ リン酸緩衝液 $5 \mathrm{~mL}$ 通液し、コンディショニングを行った。次に試料溶 液 $10 \sim 20 \mathrm{~mL}$ を通液し, $5 \mathrm{mmol} \mathrm{L}^{-1}$ リン酸緩衝液 $3 \mathrm{~mL}$ 洗浄した. 溶離液として, $4 \mathrm{~mol} \mathrm{~L}^{-1}$ 塩化ナトリウム水溶液 $3 \mathrm{~mL}$ を通液し, $5 \mathrm{~mL}$ のメスフラスコに受け, 定容したも のを分析に供した。いずれも通液速度は約 $2 \mathrm{~mL} \mathrm{~min}^{-1} て ゙$ 行った。 また, 空試験として, $\operatorname{Cr}(\mathrm{VI})$ を含まない純水 20 $\mathrm{mL}$ について同様の手順を行った.

\section{$2 \cdot 4 \mu \mathrm{PAD}$ よる $\mathrm{Cr}(\mathrm{VI})$ の分析手順}

作製した $\mu \mathrm{PAD}$ の四隅の検出部に，マイクロピペッター により, $10 \mathrm{~g} \mathrm{~L}^{-1}$ の DPC 溶液 $1 \mu \mathrm{L}$ 及び $0.1 \mathrm{M}$ の塩酸 $0.5 \mu \mathrm{L}$ を滴下した，室温で自然乾燥後，試料溶液を $\mu \mathrm{PAD}$ の中心 に滴下し, 試料溶液を検出部に到達させ, 発色試薬との呈 色反応を行った（Fig. 1 (c)). 室温で自然乾燥したのち, スキャナー（Canon，TS9030）を使用して $\mu \mathrm{PAD}$ の画像を $\mathrm{PC}$ に取り込み, 既報 ${ }^{37}$ に従い検出部の強度を画像処理ソ フト $(\text { ImageJ }(\mathrm{NIH}))^{38)}$ で解析した。

\section{3 結果と考察}

\section{$3 \cdot 1$ 滴下試料体積の影響}

Fig. 2 にPAD に滴下する試料体積の影響について検討 した結果を示す。ここでは, $\mathrm{Cr}(\mathrm{VI})$ 濃度 $20 \mu \mathrm{g} \mathrm{L} \mathrm{L}^{-1}$ の試料 溶液 $20 \mathrm{~mL}$ を用い, 濃縮操作を行ったのちの溶液を $\mu \mathrm{PAD}$ で分析した，これょり, 試料体積の増加に伴い, 強度も直 線的に増加しており, 試料体積の増加によって感度の向上 が可能であることが分かった。 しかしながら，試料体積が $60 \mu \mathrm{L}$ の場合, 乾燥に約 80 分と長時間を要した。試料体積 の増加により乾燥時間も長くなるため, ここでは試料体積 として, 乾燥時間が約 30 分であった $30 \mu \mathrm{L}$ を選択した.

\section{$3 \cdot 2$ 共存イオンの影響}

$\mathrm{Cr}(\mathrm{VI})$ 濃度 $10 \mu \mathrm{g} \mathrm{L}^{-1}$, 共存金属イオン $(\mathrm{Ba}(\mathrm{II}), \mathrm{Ca}(\mathrm{II})$, $\mathrm{Cu}(\mathrm{II}), \mathrm{Fe}(\mathrm{III}), \mathrm{Mg}(\mathrm{II}), \mathrm{Ni}(\mathrm{II})$ 及び $\mathrm{Pb}(\mathrm{II}))$ 濃度 $100 \mu \mathrm{g} \mathrm{L} \mathrm{L}^{-1}$ 


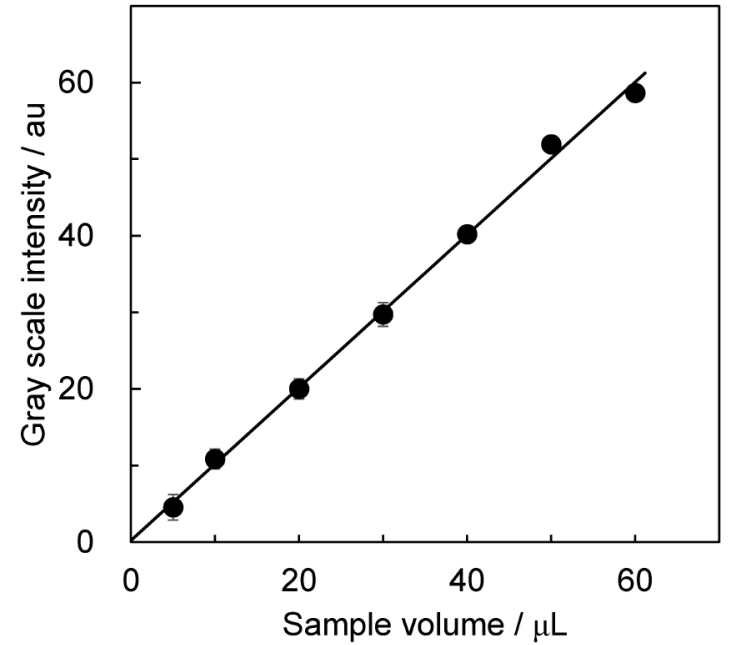

Fig. 2 Effect of the sample volume on the gray scale intensity

$\mathrm{Cr}(\mathrm{VI}), 20 \mu \mathrm{g} \mathrm{L} \mathrm{L}^{-1}$. Each data is the mean of four measurements; error bars represent the standard deviations of these measurements.

となるように試料溶液を $20 \mathrm{~mL}$ 調製し，固相抽出操作を 行ったのち, $\mu \mathrm{PAD}$ で分析した. 呈色部の画像解析を行っ た際の強度を Fig. 3 に示す。これより, $\mathrm{Cr}(\mathrm{VI})$ のみの強度 と比較して，他金属イオンの存在による大きな強度差はみ られなかった。したがって,これら他金属が $\mathrm{Cr}(\mathrm{VI})$ 濃度の 10 倍の濃度で存在していても, 定量に影響を与えないこと が分かった. DPC は $\mathrm{Cr}(\mathrm{VI})$ に対し選択的な発色試薬であ るが, $\mathrm{Fe}(\mathrm{IIII})^{\left.11)^{21} 39\right)}$ や $\mathrm{Cu}(\mathrm{II})^{21}$ は, $\mathrm{Cr}(\mathrm{VI})$ と同程度の濃度 であっても妨害することが報告されている。この場合，マ スキング剂の添加により妨害元素の除去を可能としてい る。一方，本法ではマスキング剤を添加することなく $\mathrm{Cr}(\mathrm{VI})$ の 10 倍量の $\mathrm{Fe}(\mathrm{III})$ や $\mathrm{Cu}(\mathrm{II})$ の影響が抑制可能で あった. $\mathrm{Ba}(\mathrm{II})^{40)}$ 及び $\mathrm{Ca}(\mathrm{II})^{41)}$ に関しても, $\mathrm{Cr}(\mathrm{VI})$ 定量に 先立ち, 妨害除去のための前処理が行われている. 古庄 $ら^{20)}$ によると, 本カートリッジは $\mathrm{Cr}(\mathrm{VI})$ に対して高選択性 を有し, 今回検討した $\mathrm{Ba}(\mathrm{II}), \mathrm{Cu}(\mathrm{II}), \mathrm{Ni}(\mathrm{II}), \mathrm{Pb}(\mathrm{II})$ に関 しては，定量的に回収されないため，DPCによる $\mathrm{Cr}(\mathrm{VI})$ への選択性というょりも, 固相抽出の段階で分離除去され ているものと考えられる.

\section{$3 \cdot 3$ 検量線}

Fig. 4 に $\mathrm{Cr}(\mathrm{VI})$ 標準溶液 $20 \mathrm{~mL}$ を用い, 濃縮操作を行っ たのちの溶液により作成した検量線を示す。これょり $\mathrm{Cr}(\mathrm{VI})$ 濃度 $0 \sim 20 \mu \mathrm{g} \mathrm{L}^{-1}$ の範囲で, 決定係数が 0.9978 と 良好な直線関係が得られた。また, 空試験值を 4 回測定し た際の検出部の強度の平均値は 7.4 であった，その際の空 試験值の $3 \sigma$ から算出した検出限界及び $10 \sigma$ から算出した 定量下限はそれぞれ， $1.3 \mu \mathrm{g} \mathrm{L}^{-1}$ 及び $4.3 \mu \mathrm{g} \mathrm{L}^{-1}$ となり,

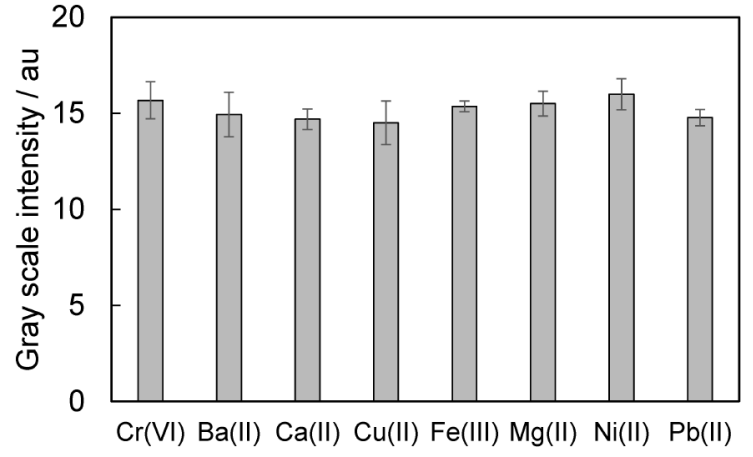

Fig. 3 Effect of foreign ions on the gray-scale intensity

$\mathrm{Cr}(\mathrm{VI}), 10 \mu \mathrm{g} \mathrm{L} \mathrm{L}^{-1}$. Foreign ions, $100 \mu \mathrm{g} \mathrm{L} \mathrm{L}^{-1}$. Each data is the mean of four measurements; error bars represent the standard deviations of these measurements.

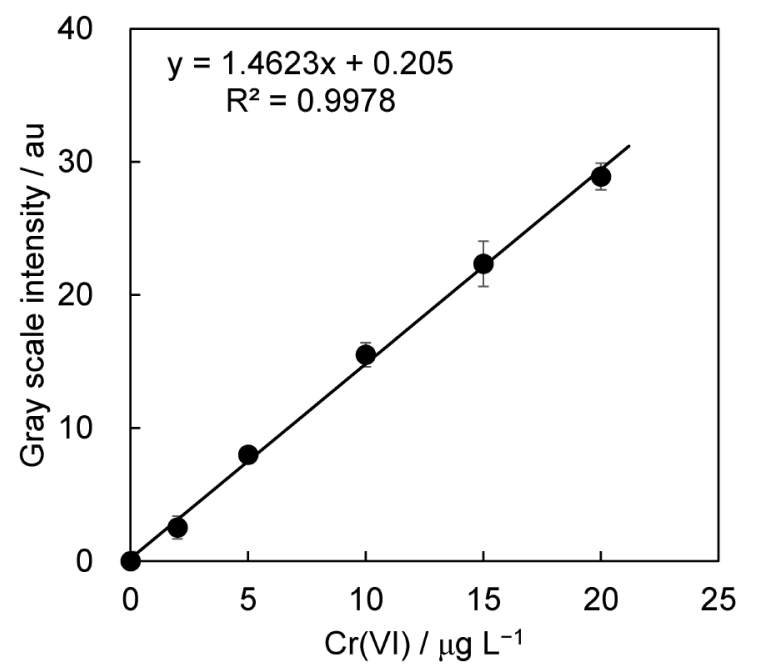

Fig. 4 Calibration graph for $\mathrm{Cr}(\mathrm{VI})$

Calibration curve is generated by measuring the gray scale intensity in detection zones. Each data is the mean of four measurements; error bars represent the standard deviations of these measurements.

$\operatorname{Cr}(\mathrm{VI})$ の高感度定量が可能となった．前濃縮により，濃縮 していない場合と比較して, 感度が約 4 倍向上した。

\section{$3 \cdot 4$ 実試料への応用}

河川水及び水道水を試料とし, $\mathrm{Cr}(\mathrm{VI})$ を添加しないもの と $\mathrm{Cr}(\mathrm{VI})$ 濃度が $10 \mu \mathrm{g} \mathrm{L}^{-1}$ となるように $\mathrm{Cr}(\mathrm{VI})$ を添加した ものについて分析を行った，その結果， Table 1 に示すよ うに, $\mathrm{Cr}(\mathrm{VI})$ 無添加は検出限界以下であったが, $\mathrm{Cr}(\mathrm{VI})$ を 添加した試料水の $\mathrm{Cr}(\mathrm{VI})$ 回収率はそれぞれ $96 \pm 0.3 \%$ 及 び $98 \pm 0.3 \%$ と良好であった。

\section{4 結 言}

本研究では高選択性樹脂を使用した固相抽出と $\mu \mathrm{PAD}$ を 
Table 1 Recovery test of $\mathrm{Cr}(\mathrm{VI})$ from water samples

\begin{tabular}{cccc}
\hline Sample & Added $/ \mu \mathrm{g} \mathrm{L}^{-1}$ & Found $/ \mu \mathrm{g} \mathrm{L}^{-1}$ & Recovery, \% \\
\hline River water $^{\mathrm{a})}$ & 0 & N.D. & - \\
& 10 & $9.6 \pm 0.3$ & 96 \\
Tap water $^{\mathrm{b})}$ & 0 & N.D. & - \\
& 10 & $9.8 \pm 0.3$ & 98 \\
\hline
\end{tabular}

a) Sawanami River in Yamaguchi, Japan. b) Tap water from Sanyo-Onoda City University. The values are the average and standard deviation of four experiments.

組み合わせた $\mathrm{Cr}(\mathrm{VI})$ の高感度分析法について検討した，そ の結果, 固相抽出による $\mathrm{Cr}(\mathrm{VI})$ の濃縮操作を行うことで, 検出限界 $1.3 \mu \mathrm{g} \mathrm{L}^{-1}$ 及び定量下限 $4.3 \mu \mathrm{g} \mathrm{L}^{-1}$ が得られ, 本法 により水質基準值 $20 \mu \mathrm{g} \mathrm{L}^{-1}$ を確認できることが明らかと なった。また，共存イオンとして $\mathrm{Ba}(\mathrm{II}), \mathrm{Ca}(\mathrm{II}), \mathrm{Cu}(\mathrm{II})$, $\mathrm{Fe}(\mathrm{III}), \mathrm{Mg}(\mathrm{II}), \mathrm{Ni}(\mathrm{II})$ 及び $\mathrm{Pb}(\mathrm{II})$ が $\mathrm{Cr}(\mathrm{VI})$ の 10 倍の濃 度で存在しても, $\mathrm{Cr}(\mathrm{VI})$ の分析に影響を与えないことが分 かった. 加えて, 本法を河川水及び水道水の実試料を用い, 添加回収試験を行ったところ, $\mathrm{Cr}(\mathrm{VI})$ は定量的に回収さ れ，測定可能であることを確認した，本法は固相抽出用の カートリッジが必要となるが, 電力を必要としないため, オンサイト分析やインフラの整備されていない開発途上国 などでの活用が期待される.

\section{謝辞}

本研究の一部は, 山陽小野田市立山口東京理科大学地域 卒業研究費及び山陽小野田市立山口東京理科大学研究推進 機構の支援によりなされたことを付記し，ここに謝意を表 します。

\section{文献}

1) 趙 一先, 張 大年, 藤森啓一, 竹中規訓, 坂東 博, 前田泰昭：環境技術, 30, 305 (2001).

2) N. Iki : Anal. Sci., 35, 1 (2019).

3) 池田康将, 土屋浩一郎, 玉置俊晃：糖尿病, 56, 919 (2013).

4) 川西正祐：日本農芸化学会誌, 61, 246 (1986).

5) 厚生労働省：水質基準項目と基準值 (51 項目), <https://www.mhlw.go.jp/stf/seisakunitsuite/ bunya/topics/bukyoku/kenkou/suido/kijun/ kijunchi.html>, (accessed 2020-12-8).

6) S. Ohira, K. Nakamura, C. P. Shelor, P. K. Dasgupta, K. Toda : Anal. Chem., 87, 111575 (2015).

7) Y. Furusho, A. Sabarudin, L. Hakim, K. Oshita, M. Oshima, S. Motomizu : Anal. Sci., 25, 51 (2009).

8) K. Hilman, 後藤 尚: 分析化学 (Bunseki Kagaku), 44, 921 (1995).

9) 若荷康志, 阿久津哲也, 清水得夫, 上原伸夫 : 分 析化学 (Bunseki Kagaku), 58, 859 (2009).

10) T. Inui, K. Fujita, M. Kitano, T. Nakamura : Anal. Sci., 26, 1093 (2010).

11) 渡辺邦洋, 東条美由紀, 板垣昌幸: 分析化学
(Bunseki Kagaku), 55, 781 (2006).

12) S. M. Ashitomi, K. Yoshimura : Anal. Sci., 29, 1093 (2013).

13) J. Wang, B. Xue : Anal. Sci., 22, 1233 (2006).

14) 堀まゆみ, 小豆川勝見, 松尾基之: 分析化学 (Bunseki Kagaku), 60, 379 (2011).

15) 本田真央, 北島信行, 阿部知子, 梅村知也, 保倉明 子：分析化学 (Bunseki Kagaku), 64, 801 (2015).

16) 宮内宏哉, 中西貞博, 山本 孝, 河合 潤: 分析 化学 (Bunseki Kagaku), 58, 321 (2009).

17) JIS K 0102, 工場排水試験方法 (2019).

18) S. Hoshi, Y. Kamada, S. Inoue, M. Matsubara : Anal. Sci., 4, 227 (1988).

19) 山本圭一郎, 中井隆行, 村上良子, 佐々木義明, 田 頭昭二：分析化学 (Bunseki Kagaku), 53, 997 (2004).

20) 古庄義明, 小野正登, 山田政行, 北出 崇, 本水昌 二：分析化学 (Bunseki Kagaku), 58, 147 (2009).

21) 大森国和, 斉藤 貴: 分析化学 (Bunseki Kagaku), 58, 801 (2009).

22) 竹之内静香, 原田雅章：分析化学 (Bunseki Kagaku), 60, 681 (2011).

23) T. Ozer, C. McMahon, C. Henry : Annu. Rev. Anal. Chem., 13, 4.1 (2020).

24) T. Kaneta, W. Alahmad, P. Varanusupakul : Appl. Spectrosc. Rev., 54, 117 (2019).

25) M. Ishii, P. Preechakasedkit, K. Yamada, O. Chailapakul, K. Suzuki, D. Citterio: Anal. Sci., 34, 51 (2018).

26) Y. Fuchiwaki, K. Goya, M. Tanaka : Anal. Sci., 34, 57 (2018).

27) Y. Shimada, T. Kaneta : Anal. Sci., 34, 65 (2018).

28) H. Asano, Y. Shiraishi : Anal. Sci., 34, 71 (2018).

29) W. Alahmad, P. Varanusupakul, T. Kaneta, P. Varanusupakul : Anal. Chim. Acta, 1085, 98 (2019).

30) H. Wang, Y. Li, J. Wei, J. Xu, Y. Wang, G. Zheng : Anal. Bioanal. Chem., 406, 2799 (2014).

31) X. Sun, B. Li, A. Qi, C. Tian, J. Han, Y. Shi, B. Lin, L. Chen : Talanta, 178, 426 (2018).

32) T. Satarpai, J. Shiowatana, A. Siripinyanond: Talanta, 154, 504 (2016).

33) S. Han, K. Hwang, R. Kwak, J. Lee : Lab Chip, 16, 2219 (2016).

34) S. Wong, M. Cabodi, J. Rolland, C. Klapperich : Anal. Chem., 86, 11981 (2014).

35) 前島健人, 江前敏晴, 磯貝 明, 鈴木孝治, チッテ リオダニエル：機能紙研究会誌, 51, 35 (2012).

36) 石井政憲, 城戸滉太, 太田 力, 柴田寞之, 山田健 太郎，鈴木孝治，チッテリオダニエル：日本画像 学会誌, 55, 94 (2016).

37) H. Asano, Y. Shiraishi : Anal. Chim. Acta, 883, 55 (2015).

38) W. S. Rasband : ImageJ, U. S. National Institutes of Health, Bethesda, Maryland, USA, <http://imagej. nih.gov/ij/>, (1997-2012).

39) A. Lace, D. Ryan, M. Bowkett, J. Cleary : Int. J. Environ. Res. Public Health, 16, 1803 (2019).

40) 柘植 亮, 斎藤麻衣, 新家淳治 : 三重保環研年報, 60, 74 (2015).

41) 田嶋 誠, 松木 葵, 刈谷玲菜, 大森真貴子, 山村 貞雄 : 高知環研所報, 31, 41 (2014). 


\title{
Sensitive Determination of Hexavalent Chromium Using a Microfluidic Paper-based Analytical Device with Solid Phase Extraction
}

\author{
Hitoshi AsAnO $^{* 1}$, Taishiro MAEDA ${ }^{2}$ and Yukihide SHIRAISHI ${ }^{2}$ \\ *E-mail : asano@rs.socu.ac.jp \\ ${ }^{1}$ Center for Liberal Arts and Sciences, Sanyo-Onoda City University, 1-1-1, Daigaku-dori, Sanyo-Onoda-shi, \\ Yamaguchi, 756-0884 \\ ${ }^{2}$ Department of Applied Chemistry, Faculty of Engineering, Sanyo-Onoda City University, 1-1-1, Daigaku-dori, \\ Sanyo-Onoda-shi, Yamaguchi, 756-0884
}

(Received December 19, 2020; Accepted February 18, 2021)

We developed a sensitive determination of hexavalent chromium (Cr(VI)) using a microfluidic paper-based analytical device $(\mu \mathrm{PAD})$ by solid-phase extraction with a highly selective resin cartridge. This resin (MetaSEP AnaLig Cr-02), which could selectively adsorb $\mathrm{Cr}(\mathrm{VI})$ was used as the preconcentration of $\mathrm{Cr}(\mathrm{VI})$ for the sensitive analysis. The diphenylcarbazide (DPC) colorimetry was utilized for a $\mathrm{Cr}(\mathrm{VI})$ assay. After solid-phase extraction was carried out, the eluent was dropped to the sample zone of the $\mu$ PAD added with DPC solution. The intensity of detection zone image for the colored $\mu$ PAD was analyzed with the image processing software to determine $\mathrm{Cr}(\mathrm{VI})$. The effect of the sample volume on the intensity was investigated, the intensity linearly increased with the sample volume. The concentration of $\mathrm{Ba}(\mathrm{II}), \mathrm{Ca}(\mathrm{II}), \mathrm{Cu}(\mathrm{II}), \mathrm{Fe}(\mathrm{III}), \mathrm{Mg}(\mathrm{II}), \mathrm{Ni}(\mathrm{II})$, and $\mathrm{Pb}(\mathrm{II})$ was 10 times higher than that of $\mathrm{Cr}(\mathrm{VI})$, but they had no effect on the determination of $\mathrm{Cr}(\mathrm{VI})$. In the range of

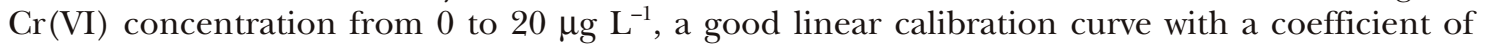
determination of 0.9978 was obtained. The detection limit and the limit of quantification were $1.3 \mu \mathrm{g} \mathrm{L}^{-1}$ and $4.3 \mu \mathrm{g} \mathrm{L}^{-1}$, respectively. The proposed method was applied to the determination of $\mathrm{Cr}(\mathrm{VI})$ in the river water and the tap water, no influence of coexisting substances was observed, and good results were obtained.

Keywords: microfluidic paper-based analytical device; hexavalent chromium; solid-phase extraction; preconcentration; diphenylcarbazide. 